Revista Água Viva

ISSN 1678-7471

\title{
O ALINHAMENTO TEORICO DA OBRA LITERÁRIA DE ARNALDO GODOY COM A ESCOLA DE CONSTANÇA E A ESTÉTICA DA RECEPÇÃO: UM LITERATO HUMANISTA E INTERDISCIPLINAR!
}

\section{THE THEORETICAL ALIGNMENT OF ARNALDO GODOY'S LITERARY WORK WITH THE SCHOOL OF CONSTANCE AND THE AESTHETIC OF RECEPTION: A HUMANIST AND INTERDISCIPLINARY LITERATURE!}

\author{
Ler um bom livro... algo tão poderoso capaz de mudar o \\ rumo da sociedade. Leia!
}

Edson Andrey de Araújo Falcão

José Eduardo Sabo Paes ${ }^{1}$

Graciane Cristina M. Celestino ${ }^{2}$

Júlio Edstron S. Santos ${ }^{3}$

Recebido em: 12 ago. 2018

Aceito em: 18 nov. 2018

DOI 10.26512/aguaviva.v3i3.23565

RESUMO: Este artigo é uma análise da obra: Direito, Literatura e Cinema - Inventário de Possibilidades, lançado pela editora Quartier Latin, no ano de 2011, do autor Arnaldo Godoy, demonstrando-se sua aproximação com a Escola de Constança e a teoria da estética recepção. Para tanto foi utilizado o método de revisão bibliográfica e principalmente a técnica hipotética dedutiva para se realizar as ilações entre o texto pesquisado e suas repercussões literárias e jurídicas. Salienta-se que a intenção foi fornecer uma crítica literária e jurídica da interdisciplinaridade apresentada por aquele literato brasileiro.

Palavras chave: Arnaldo Godoy, Direito Literatura, Escola Constança, Teoria da Recepção.

ABSTRACT: This paper is an analysis of the work Law, Literature and Cinema - Inventory of Possibilities, edited by the publisher Quartier Latin in 2011, by the author Arnaldo Godoy, demonstrating his approach to the School of Constance and the Theory of Reception. For this purpose, the method of bibliographical revision was used, mainly the hypothetical deductive

\footnotetext{
${ }^{1}$ Doutor pela Universidade Complutense de Madri. Professor da Pós-Graduação Stricto Sensu em Direito da Universidade Católica de Brasília (UCB). Coordenador Geral do NEPATS. Procurador de Justiça do MPDFT. Email: sabopaes@terra.com.br.

${ }^{2}$ Doutoranda em Literatura pela Universidade de Brasília (UnB). Licenciada em Letras (Português/Inglês) pela Universidade Estadual de Goiás (UEG). Mestra em Educação pela UnB. Professora Adjunta III, de Língua e Literatura de expressão Portuguesa e Inglesa no Centro Universitário Planalto do Distrito Federal (UNIPLAN). Email: caeiro3@gmail.com.

${ }^{3}$ Doutorando em Direito pelo Centro Universitário de Brasília (UNICEUB). Mestre em Direito Internacional Econômico pela UCB/DF. Coordenador do Curso de Direito do UNIPLAN/DF. Membro dos grupos de pesquisa Núcleo de Estudos e Pesquisas Avançadas do Terceiro Setor (NEPATS) da UCB/DF e Políticas Públicas e Juspositivismo, Jusmoralismo e Justiça Política do UNICEUB. E-mail: edstron@ yahoo.com.br.
} 
technique to make the results between the text searched and its literary and legal repercussions. It is emphasized that the intention was to provide a literary and legal critique of the interdisciplinarity presented by that Brazilian writer.

Keywords: Arnaldo Godoy, Law Literature, School of Constance, Reception Theory.

\section{INTRODUÇÃO}

Direito e Literatura são termos polissêmicos que expressam diversas dimensões da ação humana. Contudo, neste texto sinteticamente o primeiro termo se refere à ciência jurídica e o segundo a arte de criação de textos. Sendo o principal liame entre eles a possibilidade de mudanças que cada um traz para a sociedade e principalmente para o indivíduo.

Assim, foi escolhido para se demonstrar a interseção entre estas duas áreas a obra do autor Arnaldo Sampaio de Morais Godoy: Direito, Literatura e Cinema - Inventário de Possibilidades, lançado pela editora Quartier Latin, no ano de 2011, que expõe com rara profundidade as ligações entre aquelas espécies de produção da genialidade humana.

Para tanto foi utilizado tanto o método hipotético dedutivo, quanto a técnica científica da revisão bibliográfica para a realização de ilações entre a obra analisada, a Literatura, cinema e o Direito, apontando os “inventários de possibilidades” entre eles.

Arnaldo Godoy é um dos raros professores da atualidade que atuam em variadas áreas com reconhecida finura, transitando entre o Direito, nacional, internacional e a literatura, inclusive, com um pós-doutoramento em Literatura pela Universidade de Brasília. Este autor pode ser apontado como um ponto a ser mais analisado pela academia devido ao método de construção teórica e estabelecimento de interdisciplinaridade que é buscado no ensino superior brasileiro.

Salienta-se que em um mundo (do trabalho) onde há uma constante demarcação de fronteiras rígidas entre áreas do conhecimento humano, inclusive, causando uma míope alta especialização, a obra analisada transcende este problema e destaca que a função do conhecimento é possibilitar reflexões que causem transformações no cotidiano das pessoas.

Neste sentido, foi estabelecido o alinhamento teórico da obra Direito e Literatura (2011) com linha literária chamada de Escola de Constança, que tem raízes europeias e ramificações mundiais e, sobretudo, com a teoria da estética da recepção que, em linhas gerais, aproxima as visões distintas do leitor e do autor. 
Para tanto nos focamos na retrocitada análise do autor tanto de livros clássicos, quanto de filmes reconhecidos, que possibilitam repercussões jurídicas e reflexões de variadas ordens, demonstrando que há pontos de contato e de tensões entre a literatura, direito e cinema. Afinal, a arte imita a vida e vice e versa!

Assim, entre o autor, texto e leitor há uma intertextualidade que é imanente à produção humana e que possibilita tanto uma mudança da pessoa que teve contato com a obra, quanto da sociedade que é alterada pela possibilidade de mudança de comportamento dos indivíduos.

Por fim, nossa constatação é que a leitura desta obra de Arnaldo Godoy (2011) é uma feliz surpresa tanto pela sutileza do método de pesquisa, que pode ser replicado, quanto pela multiplicidade de fontes que enriquece o pesquisador e principalmente qualquer leitor que tenha contato com a sua produção.

\section{UMA VISÃO CRÍTICA DAS APROXIMAÇÕES DA OBRA DE ARNALDO GODOY E A ESCOLA DE CONSTANÇA}

Direito $^{4}$ e Literatura ${ }^{5}$ são áreas de atuação do ser humano, que se conectam pela intensa ação humana de estabelecer os limites e o alcance dos fenômenos que nos rodeiam através da interpretação dos fatos e dos signos. Sendo, portanto, os textos o sustentáculo das atividades desenvolvidas por literatos e juristas.

Porém, enquanto a hermenêutica jurídica impõe um padrão normativo externo através da absolvição de normas heterônomas, à atividade literária se conectam os valores subjetivos dos seus leitores. Nesse sentido, a recepção dos escritos em cada uma dessas duas áreas, sendo que cada um ao seu modo, contribuem para o desenvolvimento das compreensões do funcionamento estatal, da sociedade e do próprio indivíduo.

Contata-se que da antiguidade à contemporaneidade ocorrem intersecções entre o Direito e a Literatura, com grandes exemplos ficcionais como Antígona de Sófocles que inicia a fundamentação da corrente jurídica de pensamento denominada de "direito natural". Bem

\footnotetext{
${ }^{4}$ Direito para Hans Kelsen (2013) é uma ciência que tem como objeto as normas jurídicas e se diferencia de um direito que basicamente é uma declaração que devido ao seu valor é positivada por um instrumento jurídico como a lei.

${ }^{5}$ Literatura seguindo o texto de Walter Benjamin (2016) se compreende as obras da Literatura no contexto de seu tempo, evidenciando que sua abrangência pode ser tanto na área da ciência quanto da história, portanto, escolheuse aqui trata-la com inicial maiúscula.
} 
como há variados textos jurídicos que transcenderam a sua essência jurígena e inspiraram escritores, como a Declaração Universal de Direitos Humanos, tendo, como exemplo, nacional o escrito de Antonio Candido ${ }^{6}$ sobre o direito a literatura.

Portanto, a Literatura e o Direito podem ser vistos, como áreas distintas, mas que se complementam em suas funções essenciais que auxiliam no desenvolvimento humano e da própria sociedade, já que a primeira descreve e a segunda normatiza condutas sociais, se amparando na leitura do mundo que nos rodeia e na interpretação dos livros de cada uma dessas áreas.

As análises e leituras de uma época são sempre permeados por diferentes visões do contexto histórico, social, cultural e político. Em que medida essa influência orienta as percepções da Literatura por teóricos e autores consagrados em suas áreas? Como a arte se relaciona de maneira tão íntima que enreda um jurista de formação em sua teia e o seduz no caminho de comparações entre conhecimentos distintos?

Caso atual é do jurista, ensaísta, escritor de ficção e professor Arnaldo Sampaio de Moraes Godoy, sendo que no cenário da ficção parece desenvolver no jurista uma recepção do texto literário que pode ser percebida como marca de sua vasta e profícua produção.

Neste artigo, faremos um exame do livro: Direito, Literatura e Cinema - Inventário de Possibilidades, lançado pela editora Quartier Latin, no ano de 2011, em que o autor com maturidade aponta conexões entre aquelas áreas distintas.

Da obra de Godoy (2011) observa-se que enquanto construção de sua época os estudos comparatistas realizam essa travessia entre a literatura de duas ou mais nações, bibliografia e outras manifestações estéticas, mas também entre a obra literária e outras áreas do conhecimento, tal como demonstraram Coutinho e Carvalhal (2011).

Por conseguinte, apresenta-se a análise do capítulo Cinema, de Arnaldo Godoy (2011), em que o autor expõe seis agudezas teóricas acerca de textos literários que foram adaptados para o cinema e ganharam certo status a partir desse movimento. As reflexões presentes no texto são originadas da recepção do autor tanto da obra quanto em relação ao filme.

O que se percebe é que há um tratamento sistemático relacionado à estrutura das narrativas, nesse sentido observam-se ressonâncias simbólicas que dão conta da memória

\footnotetext{
${ }^{6}$ Utilizamos este exemplo devido à lição cardial apresentada por Cândido (2004) que aproxima o Direito e a Literatura, inclusive, como um valor humano e logo universal.
} 
enquanto instância que entrelaça a experiência ficcional, não há leitura de acontecimentos, mas de metáforas imbuídas de significação, uma constância da narrativa ficcional que é radicalizada para o cinema enquanto manifestação estética ligada à Literatura.

Ao iniciar a leitura de uma narrativa, a percepção do leitor é em via um caminhar iniciático, ao fenômeno leitor em que o sujeito é formado por várias culturas, pode-se denominar de construção identitária singular. Ressalta-se que as leituras literárias, adaptações fílmicas e suas respectivas manifestações estéticas, nem sempre conseguem conviver em harmonia, pois elas são contraditórias, o que o leitor percebe pode não ser o que lhe constitui enquanto agente social de uma realidade e vivência de mundo (DALVI; REZENDE; JOVERFALEIROS, 2013).

Destarte, analisa-se neste texto como são definidas as expectativas estéticas que a mesma produz, pois se a maioria dos leitores não reconhece seu papel, como ocorrerá identificação do prazer da leitura? (JOUVE, 2012). Esta concepção de leitura intertextual nos é apresentada por Godoy (2011) ao desenvolver análise que reflete os valores que são remetidos à produção de uma atividade embasada na cultura de trabalho interior e exterior, e como pode refletir na ação consciente.

Ao descrever o momento de leitura como aquele que inter-relaciona texto e leitor, este teórico analisa as relações de conhecimento prévio, as concepções de intertextualidade ${ }^{7}$, as noções de estrutura narrativa, a função da leitura e a recepção da obra.

Depreende-se daí que há um esforço do ente estudado por discutir a impropriedade da dicotomia fantasia versus realidade. A percepção que se tem é de um teórico profundamente marcado pela experiência leitora e superação de dificuldades, em uma constante associação com o conhecimento e a transformação da realidade, Como exemplo, o seu texto ficcional amigos da F.O.M (Godoy 2018).

A construção da imaginação e transfiguração da realidade parece provocar em Arnaldo Godoy (2011) curiosidade e motivação para adentrar uma área de conhecimento que o possibilite escolher suas próprias leituras além de experiências culturais, por conseguinte, consciente ou inconscientemente, ele apresenta conceitos próprios de uma corrente literária que se desenvolveu a partir da Escola de Constança da estética da recepção, tendo como seu

\footnotetext{
${ }^{7}$ Intertextualidade para Kristeva é: "todo texto se constrói como mosaico de citações, todo texto é absorção e transformação de um outro texto. Em lugar da noção de intersubjetividade, instala-se a de intertextualidade”. Ver: KRISTEVA 1974a, p. 64, grifo nosso.
} 
principal teórico Wolfgang Iser, que na década de 1970 lançaria seu texto $O$ ato da leitura (1978).

Essa provocação do imaginário e sua transfiguração podem ser motivadas pelas escolhas empreendidas pelo jurista, pois ao apresentar os conceitos que se desdobram em sua análise há acréscimos e tessituras textuais que o familiarizam com a intertextualidade, conceito presente em $O$ ato da leitura (1978).

As áreas do conhecimento possibilitam diversificadas recepções por parte do leitor e Godoy (2011) percebe esse ato em sua estrutura de análise dos textos.

Nessa perspectiva ocorre sua aproximação, sendo que o ponto de partida da chamada Estética da Recepção, que foi teorizada na aula inaugural de Hans Robert Jauss, em 1967, na Universidade de Constança, o título da aula foi Literaturgerschichte als Provokation der Literaturwinssenschaft, a partir dessa lição reuniram-se em torno da chamada "Escola de Constança", nomes como os de: Wolfgang Iser, Hans Neuschäfer, Hans Ulrich Gumbrecht, Karlheinz Stierle e Manfred Fuhrman, as ideias de Jauss ao contrário de Gadamer que se concentrava exclusivamente no passado, buscaram examinar o papel do leitor na literatura e sua recepção enquanto fundamento da narrativa fictícia, Eagleton (2006).

Mais tarde a Escola de Constança corresponderia na República Democrática Alemã ao "Grupo de Berlim" do qual faria parte Manfred Naumann, bem como demonstrou Figurelli (1988), recebendo reconhecimento internacional e influenciando estudiosos do mundo inteiro.

Tendo por pressuposto essa intenção dos teóricos da Estética da Recepção, Iser (1970), situa o ato de ler como uma necessária familiaridade entre técnicas e convenções literárias, o que Godoy (2011) semelha desenvolver em seu texto, nesse sentido a abordagem do teórico citado é imbuída dessa "familiaridade", pois sua percepção da leitura se relaciona com a compreensão de seus códigos, tanto que em suas análises, que serão tratadas caso a caso, ele discute cada um dos temas e os trata com rigor metodológico. Em consonância com o pensamento de Iser (1970). Também o crítico literário Terry Eagleton (2006) cita que:

Para Iser, a obra literária mais eficiente é aquela que força o leitor a uma nova experiência crítica de seus códigos e expectativas habituais. A obra interroga e transforma as crenças implícitas com as quais a abordamos, "desconfirma" nossos hábitos rotineiros de percepção e com isso força a reconhecê-los pela primeira vez, como realmente são. Em lugar de simplesmente reforçar as percepções que temos, a obra literária, quando valiosa, violenta ou transgride esses modos normativos de ver e com isso nos ensina novos códigos de entendimento (EAGLETON, 2006, p.119-120). 
Eagleton (2006) ao se referir a Iser (1970) demonstra que sua compreensão da obra literária abrange a experiência leitora como aquela que possibilita escolhas, amplia repertórios, além de constituir- se de uma experiência de recepção interior, pois ao citar o fato de que Iser (1970) compreendia a obra como aquela que pode modificar e ampliar o reconhecimento de novos códigos, ele também desmistifica a $a$-historicidade hermenêutica de uma obra, ou então a análise dos fenomenologistas, sua relação entre o espaço textual e o fílmico que nos apresenta Godoy (2011), pode ser uma boa abordagem para compreender em que medida essas experiências culturais e sociais advindas do ato de ler constituem significados.

Deste modo, compreende-se o texto literário e sua adaptação para o cinema como espaço de interação que comporta um meio ficcional, o prolongamento dos sentidos é um desdobramento da ação narrativa, as figuras de leitura, a interpretação que pode ser modelada por chaves dadas pelo texto matriz, mas que só podem ser acionadas pelo leitor, a nosso ver assemelham-se a algumas das motivações que Godoy (2011) apresenta para analisar as adaptações cinematográficas, a crítica como processo de criação de significados.

Neste sentido, o objeto não está dado, pois só pode ser construído pelo leitor. Essa experiência da modernidade indica a narração como uma das mais antigas formas de recepção da obra literária. O cuidado sistemático que é dado pelo jurista é de que o objeto estético não seja reduzido ao papel da sensação sem que haja interlocução com a experiência, essas possibilidades se apresentam como maneiras de ressignificar a articulação do espaço literário, desenvolvendo assim chaves para sua compreensão, que podem ser: percepções, sensações e suposições, nesse sentido Godoy (2011) apresenta a mudança da estrutura da narrativa ao adaptar o texto para o cinema, então há comparação com a linguagem, relações intertextuais, comparação com o tempo delimitado da obra de arte, leitura que agrega elementos, montagem de imagens e a relação texto-leitor. Proporcionando outra experiência para além da leitura da obra em si.

Apresentam-se a seguir algumas formulações acerca das análises de: $O$ nome da rosa, de 1986; O leitor, difundido em 2009; Lanternas vermelhas, distribuído em 1991; A vida dos outros, espargido em 2006; Tempo de matar, do ano de 1997; Sob a mesma lua, de 2010, os seis filmes compõem o capítulo Cinema, do livro Direito, Literatura e Cinema em que o autor dispõe, com reconhecida maturidade, suas impressões e percepções acerca das relações entre direito e literatura, onde segundo ele: 
Num primeiro momento, buscava alcançar aspectos jurídicos na produção literária de ficção. Mas também a literatura no [grifo do autor] direito, designadamente, uma pretensão de se fazer teoria e crítica literárias em textos jurídicos, que variam de decisões judiciais a petições, com estações em excertos de doutrina; neste caso, toca-se em material burocrático, que não despreza o conteúdo das próprias normas jurídicas (GODOY, 2011, p.12).

Pressupõem-se nesse sentido que o autor relacione o Direito enquanto área do conhecimento com a extensão de uma crítica literária que possa empregar aspectos textuais para produzir sentidos e significados diferenciados à sua produção teórica.

Ao escolher as análises fílmicas relacionadas ao capítulo dedicado ao Cinema de seu livro, buscou-se refletir acerca de como se constituem a partir de textos literários e como foram utilizados os conceitos de intertextualidade presentes na estética da recepção da Escola de Constança e narrativa fílmica, conceito abordado por Carlos Reis em seu Dicionário de Estudos Narrativos (2018).

\section{Seis análises fílmicas e seus desdobramentos conceituais}

Logo no início de sua análise de $O$ nome da rosa o autor cita a tradição que é constituída na obra utilizando como referência os chamados universais, discussão da Idade Média acerca da importância das coisas e seus nomes, notável devido ao desenvolvimento de interdisciplinaridade entre a Literatura e Direito, é que na análise é citado o conceito de intertextualidade. Essa indicação se mantém em:

\footnotetext{
Na obra de Eco há inúmeras referências simbólicas de conteúdo interminável. Jorge de Burgos, o guardião cego da livraria, é homenagem explícita ao escritor argentino Jorge Luís Borges. Há também inegáveis semelhanças entre o conto A Biblioteca de Babel, de Borges, e alguns pontos temáticos de $O$ nome da Rosa, a exemplo da recorrência a espelhos e labirintos, construções comuns na temática borgeana. $\mathrm{O}$ que não deixa de ser uma brincadeira bem ao estilo de Borges (GODOY, 2011, p. 377).
}

Observe-se que em seu processo de recepção da narrativa fílmica em questão, Godoy (2011) constrói uma linha de referências que irão nortear sua análise, nesse excerto, ao citar um 
dos aspectos, a influência de Borges na obra de Eco, ele designa os pontos temáticos que cita como oriundos de um dos textos de Borges, há que se recorrer à Emir Rodrigues Monegal (1980), crítico literário uruguaio, para analisar essa questão, pois a escrita borgeana se constituí de uma poética da leitura, alguns de seus referenciais ao produzir reflexões metafísicas eram justamente os citados por Godoy (2011), espelhos e labirintos, por se inter-relacionar com as discussões filosóficas que rodeavam o autor, principalmente as que estavam ligadas à Idade Média.

Outro ponto de intertextualidade segundo este teórico é encontrado nas citações do filósofo William de Ockham, Os cães de Baskerville e personagens como Adso que faz alusão a Watson de Sherlock Holmes. Destarte, compreende-se que a empreita de Godoy (2011) esteja ligado ao conceito que permeia a Literatura Comparada ${ }^{8}$, que é o de intertextualidade, a intenção do presente texto é refletir essas questões utilizando para isso em um primeiro momento as influências que são examinadas a partir de uma vasta gama de fenômenos e pontos de vistas que nos são apresentados para que se compreenda a centralidade do enredo e sua abrangência na Idade Média.

Será que esta variedade, como já foi sugerido, expressa a proximidade do campo com a complexa tessitura da história literária, ou da própria história, o que é, em última análise, uma qualidade? Este pode muito bem ser o caso. Mas antes que a heterogeneidade dos estudos comparativos seja avaliada, é indispensável que ela seja mais uma vez examinada e compreendida (COUTINHO; CARVALHAL, 2011, p.170).

A compreensão do campo de atuação do conceito de intertextualidade na Literatura Comparada aqui se dá por sua interação com a tessitura literária, em sua análise ela busca refletir acerca das aproximações e estudos heterogêneos que a compõem enquanto conceito nos estudos comparatistas, ao que parece o jurista se muni de variadas estratégias comparatistas para organizar sua análise, percebe-se que ao analisar tais textos ele concretiza a obra literária, a partir de sua intervenção enquanto leitor, assim como apregoa a estética da recepção, a

\footnotetext{
${ }^{8}$ Literatura Comparada implica um estudo de literatura que usa a comparação como seu principal instrumento. In: COUTINHO; CARVALHAL, 2011, p. 313.
} 
composição da obra por "hiatos" é empregada como uma conexão que inexiste, mas se apresenta.

Em uma análise que relacione ambos os textos, O nome da Rosa e $O$ Leitor, a partir da leitura teórica em Godoy (2011), pode-se afirmar que,

Para a teoria da recepção, ele é sempre dinâmico, um movimento complexo que se desdobra no tempo. A obra literária existe apenas como algo que o teórico polônes Roman Ingarden chama de uma série de schemata, ou direções gerais, que o leitor deve tornar realidade. Para isso ele abordará a obra com certos "pré-entendimentos", um vago contexto de crenças e expectativas dentro dos quais as várias características da obra serão avaliadas. (EAGLETON, 2006, p.117).

O ele, a que se refere no excerto acima diz respeito ao texto, pois segundo Eagleton (2006), foram produzidas reações diferentes em diferentes leitores tendo por base o dinamismo do texto e seu movimento, o que aqui se quer indicar é como se apresenta a análise fílmica de "O leitor" em Godoy (2011), a primeira indicação no texto do autor é sua narrativa inicial do filme, o que logo depois substitui por uma análise dos sentimentos ali refletidos a partir de uma indicação de ensaio acerca da cultura alemã, de Habermas (2003), ao se referir ao filme o cita como "corajoso", pois se trata de uma narrativa que situa os sentimentos e tensões advindas do nazismo na Alemanha.

Durante toda a análise de Arnaldo Godoy (2011) suas impressões enquanto receptor são testemunhadas por assertivas como, "A primeira cena retrata Michael em Berlim, em 1995, preparando-se para ir para o trabalho" (GODOY, 2011, p. 382), seu relato inicial dá conta de uma situação da personagem Michael, protagonizada por Ralph Fiennes, em que o jurista realiza um movimento típico dos estudos literários comparatistas, ele analisa a cena presente, 1995, e a inter-relaciona com uma situação vivenciada pelo protagonista em 1958, narrando as vicissitudes comportamentais da personagem, imerso no seu cotidiano histórico e subjetivo.

O que em $O$ nome da Rosa também é realizado quando Godoy cita o fato de os padres franciscanos serem, durante a Idade Média, vigiados pela Inquisição, o que é citado pelo jurista como uma primeira concepção de criminologia moderna, sua perspectiva é intertextual em cada uma das relações textuais encadeadas a partir de uma tela de acontecimentos comuns às pessoas. 
Em conexão com outro teórico advindo da Escola de Constança, Hans Ulrich Gumbrecht, analisa essa produção de conhecimento, como uma "orientalização ensaiada da experiência estética” (GUMBRECHT, 2016, p. 08), sua concepção de recepção vem de encontro ao conceito de sentido e se dedica a explanar acerca de como a produção de sentido pode ativar a consciência textual, o que é se reconhece nas análises de Godoy, ao reconhecer as relações textuais e com o mundo que se apresentam, tal como demonstra o excerto abaixo:

Tal ambiente existencial produz agilidade mental, flexibilidade e, talvez, mesmo uma camada em nossas vidas cotidianas que merece ser associada com conceitos como "liberdade" e "independência". Ao mesmo tempo e, acima de tudo, acredito, tal ambiente produz um desejo por formas às quais possamos nos agarrar, existencial e fisicamente, assim como um desejo de recuperar espaço ao nos tornarmos parte de " corpos místicos" ou de "corpos coletivos" (GUMBRECHT, 2016, p. 106).

Gumbrecht (2016) foi aluno de Hans Robert Jauss, outro grande nome da estética da recepção, muito influenciado pela obra de Martín Heidegger, sendo que o seu pensamento repercute as relações de presença e constituição do espaço da linguagem e sua recepção, nesse sentido ao denotar a produção de agilidade mental e física, o teórico da recepção nos remete à análise realizada por Godoy (2011) em "Lanternas vermelhas" e "A vida dos outros", em que o jurista apresenta sua "produção de presença" a partir da análise do momento histórico, político e social em que se encontra a China de 1920, logo após a queda do Império Qing e a consolidação da república, o que se apresenta em Lanternas vermelhas, o autor cita então que:

Não é por acaso que a personagem principal era uma jovem universitária de 19 anos, chamada de Songlian. Ela abandonou os estudos, depois da morte do pai, por determinação da madrasta, casando-se com Chen Zuogian, um senhor feudal de meia idade, que mantinha ainda outras três esposas, em seu imenso castelo. É nesse simbólico espaço que os fatos que seguem se desdobram (GODOY, 2011, p. 388).

Durante toda a narrativa analítica de Godoy (2011) sua descrição da presença e relações discursivas relacionadas a gênero se condensam em apresentar ao leitor a recepção de como Songlian se relaciona com Chen Zuogian, observa-se aqui uma consciência de natureza do ato 
criativo em arte, o que se destaca na finalização da leitura teórica em que o autor apresenta tal filme como uma denúncia contra a submissão feminina, o que indica, nas palavras de Godoy: “ilustra adequadamente discussões relativas a problemas de gênero". (2011, p. 391)

Como cita Eagleton (2006), o ato de interrogar e transformar as crenças vigentes força o leitor a uma consciência de códigos e expectativas habituais, essa formulação é facilmente notabilizada quando há referências mesmo que difusas aos excessos empreendidos por abordagens que buscam descentrar o ato da recepção, em $A$ vida dos outros, ao citar que:

Ao longo do filme, percebe-se uma mudança radical nas atitudes de Weisler.
E se nas primeiras cenas ele se revela como um inquisidor implacável,
fidelíssimo ao regime, constata-se uma alteração em seu comportamento, cujo
clímax é atingido em uma das últimas cenas, na qual Weisler dá fim à única
prova que poderia incriminar o diretor Georg Dreyman: uma máquina de
escrever que fora utilizada na composição de textos negativos sobre a
Alemanha Oriental, que foram divulgados no exterior (GODOY, 2011, p. 392).

Durante sua análise este teórico buscou refletir acerca das percepções e mudanças, além de se referir a casos relacionados à jurisprudência brasileira em consonância com a narrativa fílmica, sua compreensão de problemáticas oriundas de sigilo fiscal e direito de intimidade, além de indicar a questão do devido processo legal, são correlacionados ao filme e sua narrativa, novamente utilizando técnicas e estratégias que são típicas dos estudos literários comparatistas modernos, além de objetivar a percepção rousseauniana, como cita logo ao final da análise, fazendo uma indicação de como até mesmo as “ mais sanguinárias ditaduras" podem contar com pessoas que se comprometem com a democracia e por ela lutam.

Sua percepção de que em "A vida dos outros", há uma nitidez da inexistência de limites em estados autoritários, possibilita reflexão acerca da crítica que tece em relação à arrogância, falta de compromisso e escrúpulos daqueles que se adonam do poder simbólico que detém em razão de um regime que segrega e sufoca, tomando por pressuposto esta reflexão pode-se observar o que cita Eagleton (2006), "Toda a função da leitura é, para um crítico como Iser, levar-nos a uma autoconsciência mais profunda, catalisar uma visão mais crítica de nossas próprias identidades" (EAGLETON, 2006, p. 120).

Godoy (2011) permanece fiel a tal reflexão, consciente ou inconscientemente, pois sua colaboração para a compreensão dos fenômenos de recepção da narrativa fílmica com questões 
relacionadas à ciência política e direito são estabelecidas a partir de sua predisposição teórica, que pode ser compreendida como utilização das estratégias de intertextualidade enquanto conceito dos estudos comparatistas. Mais adiante, ao refletir acerca de "Tempo de matar" e "Sob a mesma lua", a vivificação de uma análise acerca da cultura popular o remete aos estudos da contemporaneidade, ambos os filmes tratam de questões da dita globalização, o que se aborda no primeiro são as manifestações estéticas ligadas à contracultura.

Em momento propício da reflexão, o teórico atenta para a desconfiança de Adorno acerca das estéticas da cultura de massa, cita a racionalidade comunicativa e discute a validade do cinema para as categorias da jurisprudência, destarte é importante pensar com Reis (2018) para quem:

Se o entendermos numa aceção ampla, reconheceremos que, no cinema (e em particular no cinema ficcional), são representados universos e figuras cuja dinâmica temporal, conflitualidade (potencial ou efetiva), sequencialidade e dimensão humana são adequadamente modelizados pela narrativa: "A tríade tempo, espaço e causalidade é, por conseguinte, um ingrediente básico do cinema narrativo" (VERSTRATEN, 2009;159), legitimando a sua intrínseca narratividade" (REIS, 2018, p. 55).

Essa configuração da recepção da narrativa fílmica considera as singularidades e participa o entendimento das tendências relacionadas à circulação de filmes, livros e leituras como sendo uma possibilidade de construção de diálogos que não se constituam em unilaterais. Isso não é uma possibilidade única e sim uma delas, de pensar a transgressão que se determina no ritual de leitura individual e solitária.

O real a ser discutido é como essas questões podem subverter o papel do leitor e se instaurar como apropriadas à compreensão de uma "cultura letrada", e essa passa por noções variadas de práticas que compreendem as apropriações de leituras realizadas.

Tais práticas envolvem também as relações entre leitura e escrita que se instauram nas limitações do texto a circular na sociedade, como sendo produto de uma experiência humana, constituída por fatores diversos, em um contexto social, histórico, econômico e político que reorganiza a maneira de pensar a subjetivação na leitura. Por isso: 
[...] certas operações de leitura exigem realmente o investimento pessoal do sujeito leitor para andar bem. É o caso, por exemplo do processo de representação. As imagens mentais construídas pelo leitor a partir do texto são, em razão da incompletude estrutural da obra (o enunciador não pode descrever tudo, nem descrever completamente), necessariamente subjetivas. O modo pelo qual um leitor imagina cenário e personagens a partir de indicações, em geral um tanto vagas do texto, remete a situações e acontecimentos que vivenciou e cuja lembrança retorna espontaneamente durante a leitura (ROUXEL; LANGLADE; REZENDE, 2013, p. 54).

Ao assinalar essas operações de leitura, que indicam o grau de incorporação da voz do outro ao texto e de sua familiaridade com a experiência e com as representações empíricas que constituem o mesmo, afinal o autor também é um leitor de algo ou alguém, consagra-se aí a percepção de que o real e sua não habitação na linguagem podem ser observados em uma medida entre o plano linguístico e o literário.

Esta constatação é passível de análise e envolve o real e sua constituição pela linguagem, pois a mesma se articula na materialidade dos signos que constituem a experiência leitora como ruptura em relação ao processo de escrita, bem como sobre a vida. Sendo assim, pode-se dizer que a linguagem comporta algo da subjetividade para o mundo real.

O processo de decodificação de experiências subjetivas de leitura é amplo e requer uma elaboração silenciosa entre a constatação de que toda escrita literária parte do real realiza uma espécie de travessia linguística e retorna para o lugar que se instaurou anteriormente, tendo sofrido transmutações nesse percurso.

Sendo assim, pode-se aqui relacionar a localização da escrita literária que está intrinsecamente ligada à sua constituição, a experiência com a travessia do signo linguístico e a segmentação da imagem à materialidade desse signo pela experiência de leitura individual e solitária que se constitui como recognição mediada pelo deslocamento.

Essa experiência de Godoy (2011) com a constituição de suas análises fílmicas se torna perceptível ao citar as condições de sobrevivência e aceitação do jurídico em uma espécie de embate, que o jurista chama de dialético, contudo a nosso ver seria de ordem comparatista, pois sua organização estrutural das análises é distribuída de maneira a versar acerca de questões relacionadas à modernidade, problematizando-a com o passado e sua relação vindoura, como no trecho abaixo de "Tempo de matar". 
$\mathrm{O}$ advogado defensor do pai vingador passa a receber ameaças de setores mais conservadores da cidade, liderados pelo irmão de um dos rapazes que fora assassinado. Grupos de defesa de direitos civis sugerem que o criminoso mude de advogado. Em atitude firme, mantém-se aliado do jovem causídico, que busca conselho com um advogado alcóolico, que fora professor, e que estava impedido de atuar em juízo, certamente por problemas decorrentes do alcoolismo. (GODOY, 2011, p. 399).

O reconhecimento das técnicas de crítica e sua relação com as condições de criação, pois o ato criativo na arte é profundamente influenciado pela sociedade, se constituem em mobilização temporal e indeterminação espacial (GUMBRECHT, 2016, p. 107), a recepção de um texto ou filme é indicada pela hipótese de trabalho interpretativo, o que a nosso ver é constituído nas análises de Godoy (2011) ao se reconhecer receptor de dada mensagem, em "Sob a mesma lua", o jurista analisa os problemas de imigração e se pauta no ponto de vista jurídico, desenvolve uma crítica à condição do estrangeiro ilegal nos Estados Unidos da América, em excertos como,

Na estória, a mãe mexicana vai trabalhar nos Estados Unidos, deixando o filho que tinha quatro anos. Cinco anos depois, o menino cruzou a fronteira, procurando a mãe, de quem tanta saudade sentia. A mãe é interpretada por Kate del Castillo, badalada atriz mexicana. No filme, adora o filho, que deixou para poder sustenta-lo. Dilema recorrente (GODOY, 2011, p. 401).

O cinema, portanto, como elemento sonoro gráfico que se constitui em variações no decurso temporal, se instaura no signo em Godoy (2011) e comporta uma experiência que pode ser pensada historicamente, pois a linguagem fílmica necessita do tempo para existir. Coexiste aí um jogo com a temporalidade na/da linguagem, porque aquele que escreve quer de alguma maneira, reforçar o espaço-tempo na escritura.

Entretanto, a literatura situa e vivencia uma incompletude de sentidos, esta sensação de falta que é definida pelas materializações sociais, históricas e culturais que são comportadas pela tensão entre o fictício e o real, ao não esgotar as possibilidades de significação. 
A leitura exige, então, um compromisso com a navegação de sentidos. Ao mesmo tempo requer uma solidificação do poder de explicitação dos mesmos, que se constitui na construção da linguagem literária, do tecido, da trama e de sua relação com a materialidade textual, com as relações sociais e culturais, com a organicidade histórica que é indicativa da escritura também como um exílio, e a leitura como isolamento. Também neste sentido:

[...] assim, se hoje todos estão de acordo em dizer que o texto literário só pode verdadeiramente existir quando é "produzido" por um leitor, é necessário distinguir claramente duas teorias da realização do texto pela leitura. De um lado, aqueles que pretendem que todos os leitores - talvez fosse conveniente dizer todos os verdadeiros leitores, isto é, aqueles que têm os meios de respeitar adequadamente as regras - se encontrarão, grosso modo, em um espaço interpretativo da obra objetivável graças à evidenciação das injunções do texto; de outro, aqueles que, como Pierre Bayard, consideram a obra literária como, por essência, "móvel", estimando que cada leitor produz um texto singular (ROUXEL; LANGLADE; REZENDE, 2013, p. 34).

Tendo no plano da construção de uma linguagem literária que relacione as recepções do leitor não apenas como divagações teóricas, em alguns casos não aprofundados, mas também que contemplem sua mobilidade e adequação à singularidade de textos e discursos, as relações que podem ser configuradas aí são de contribuição entre expressões culturais.

A Literatura permite que se pense na realização de sentidos e explicitação dos processos de compreensão e saber que conduzem à valorização do discurso literário de um autor em um determinado momento histórico-social e sua contribuição no ato de pensar o poder comunicacional da leitura literária.

Os ensinamentos resultantes da experiência de grandes leitores/autores com o texto é uma das possibilidades que aqui se apresentam como pensar a análise e compreensão da fundamentação de um processo de leitura estética que produz no leitor em formação diferenciadas significações acerca da sua identidade e constituição leitoras.

A cultura, em uma de suas possíveis conceituações, pode ser considerada como uma tradição do fazer humano que é transmitido de geração a geração, e, segundo Canclini (2015), como modalidades de hibridação relacionadas aos diferenciados extratos da cultura latinoamericana. No caso específico do objeto de estudo e do público alvo que será pesquisado, o 
autor utiliza os termos cultura urbana e cultura popular para se referir aos rótulos relacionados ao culto e ao popular.

Essa tensão entre o culto e o popular já teria sido indicada por Canclini (2015), sendo salientada aqui com o intuito de analisar até que ponto esses rótulos operam nas leituras realizadas um distanciamento do que é entendido como culto. Essas transformações podem ser compreendidas como tendo desenvolvido no ser uma soma de realizações que confluem em linguagem, que é, ao mesmo tempo, uma condição para sua existência. Este autor ainda entende como "o entrecruzamento de muitas forças da modernidade, a "explicação" de seus nós e suas crises" (CANCLINI, 2015, p. 285).

Nesse espaço de construção reflexiva acerca das análises fílmicas dispostas em Godoy (2011), podem-se perceber as considerações densas que se estabelecem, apesar de não estar ambientado em uma crítica literária, o jurista utiliza em muitas de suas análises o conceito de intertextualidade que permeia os estudos de literatura comparada e sua importância para a compreensão das relações entre literatura, cultura, política, sociedade e estado.

\section{CONSIDERAÇÕES FINAIS}

A análise dos estudos comparatistas é uma realidade do trabalho de Arnaldo Godoy, buscou-se no presente artigo evidenciar suas fontes e contextualizá-las em relação à passado e presente, pois, durante suas indagações e perspectivas se instaura a presença de uma contribuição do Direito enquanto área do conhecimento e ciência para a Literatura, enquanto arte e área do conhecimento. Entre os textos analisados há restauração de estruturas típicas da Estética da recepção, em que são contemplados os leitores enquanto instância.

Assim, esta pesquisa e análise dos seis textos contemplados pelo capítulo Cinema, do livro Direito, Literatura e Cinema: inventário de possibilidades, situa-se em uma construção analítica do texto e sua recepção, confrontando nesse espaço a percepção do teórico acerca do que se estabelece enquanto narrativa fílmica, tendo por finalidade oferecer uma crítica literária a partir das percepções de um teórico e jurista, sendo que as considerações são a nosso ver, propositivas. Crê-se que a leitura do processo de recepção dos livros e filmes por Arnaldo Godoy seja uma maneira de reconhecer a importância da convergência entre áreas na Literatura 
Comparada, pois pode-se observar nos textos concebidos pelo jurista sua construção identitária enquanto leitor, além de indicar como a Literatura pode contribuir para sua área de conhecimento de maneira ampla.

Destarte, ao final desse artigo observa-se a compreensão que o teórico suscita em relação à construção de uma produção de presença que caracterize como se dá a recepção de um texto ou filme, essa constituição é sentida durante a leitura das seis análises aqui contempladas. Nessa concepção utilizou-se do ponto de vista metodológico a revisão bibliográfica em uma contextualização literária, e o conceito de intertextualidade que orienta a Literatura Comparada enquanto área, pois não há uma corrente filosófica que a aborde, e sim um conceito, partiu-se, portanto, do preceito de produção de presença, recepção da obra literária e crítica da referida produção fílmica e sua contextualização por Godoy (2011) dentro da teoria literária e de análise e do Direito.

A estética da recepção expressa às relações que se apresentam entre obra e receptor, neste sentido utilizaram-se as análises de Godoy (2011) por se tratar de criação artística, que foi incorporada ao escopo de produção teórica do jurista como sistematiza a literatura comparada enquanto área, que de acordo com este reconhecido literato são recebidas como construto de uma imaginação estética.

Por conseguinte, compreende-se com Arnaldo Godoy (2011) que toda literatura a seu tempo comporta algum tipo de resistência a algo ou alguém, pois “todos os homens buscam alcançar o sentido da própria existência e se interrogam sobre os porquês das desigualdades que saltam à vista, e só não existem para aquele triste cego, o pior de todos, que não quer ver" (BOSI, 2002, p. 267).

Embora proveniente de área do conhecimento diferenciada da Literatura, Godoy consegue visualizar as deformidades e fragilidades que polarizariam confrontos e violações em tempos vindouros por meio de sua recepção dos textos, além de relacionar cada uma das análises com alguma das doutrinas jurídicas. O presente trabalho foi, portanto, uma reflexão acerca das significações que as narrativas fílmicas suscitaram no jurista e qual sua compreensão da atualidade e suas possibilidades de análise e organização de conceitos.

Analisa-se ainda que Arnaldo Godoy, jurista, teórico e professor da área do Direito, busca em seus textos retratar situações que possam estabelecer um parâmetro de estudo comparado entre a Literatura e o Direito, além de discutir questões de cultura e arte. Ao situar 
a perspectiva da estética da recepção, da Escola de Constança, contemplaram-se as estruturas sistematizadas pelo jurista e como suas perspectivas tem estreita relação, mesmo que inconsciente, com Jauss e Iser, seu posicionamento científico é exemplificado em relação às marcas de produção que a constituem, sendo seu trabalho, a nosso ver, profundamente marcado pelo comparatismo.

Os meandros dos textos relacionados constituem um processo de recepção leitora que se relaciona e discute a forma estética, refletindo acerca do papel social da arte, de sua constituição e da relevância da cultura e da experiência com a intertextualidade, que encontrase em Kristeva (2009) e em Rouxel, Langlade e Rezende (2013), pois esse questionamento, denotado por Godoy (2011) acerca do sentido evocado no leitor, é um ato de recepção. Destarte, a leitura tem sentido para o leitor quando é sensível à sua busca, o que reconfigura questões relacionadas à apropriação de um texto, ação voluntária, desejo de leitura. Sendo assim, atualmente observa-se o constante crescimento de gostos literários.

Destarte, ao se ler pela primeira vez as análises de Godoy (2011), o leitor é surpreendido com a riqueza de fontes, o processo de pesquisa e leituras, além das relações que foram estabelecidas pelo jurista. Desta maneira, as reflexões que são apresentadas no presente trabalho, operam a organização de pesquisas, além de buscar a compreensão de como o autor utiliza, consciente ou inconscientemente, estratégias que são típicas dos estudos literários comparatistas modernos, tendo em foco a recepção que o mesmo indica. Por conseguinte, a proposição do presente artigo, é pensar a composição do trabalho de Arnaldo Godoy, suas nuances, os aspectos relacionados à Literatura e ao Direito e suas perspectivas teóricas.

\section{REFERÊNCIAS}

BENJAMIN, Walter. História da literatura e ciência da literatura. Tradução de Helano Ribeiro; Manoel Ricardo de Lima. Rio de Janeiro: 7 letras, 2016

BOSI, Alfredo. Literatura e resistência. São Paulo: Companhia das Letras, [1936] 2002.

CANCLINI, Néstor García. A sociedade sem relato: antropologia e estética da iminência. Tradução de Maria Paula Gurgel Ribeiro. São Paulo: Editora da Universidade de São Paulo, 2016.

CANDIDO, Antonio. Vários Escritos. São Paulo: Ouro Sobre Azul, 2004.

COUTINHO, Eduardo F.; CARVALHAL, Tânia Franco. (Orgs.). Literatura comparada: textos fundadores. Rio de Janeiro: Rocco, 2011. 
DALVI, Maria Amélia; REZENDE, Neide Luzia; JOVER-FALEIROS, Rita (Orgs.). Leitura de literatura na escola. São Paulo: Parábola, 2013.

EAGLETON, Terry. Teoria da literatura: uma introdução. Tradução de Waltersin Dutra; [Revisão de tradução João Azenha Jr.]. São Paulo: Martins Fontes, 2006. (Biblioteca universal)

GODOY, Arnaldo Sampaio de Moraes. Direito, Literatura e Cinema: Inventário de possibilidades. São Paulo: Quartier Latin, 2011.

O caso do julgamento dos membros da f.o.m (amigos da humanidade). In: REPATS, v. 4. n. 2, jul/dez, 2017. Brasília. Disponível em:

<https://portalrevistas.ucb.br/index.php/REPATS/article/view/8916/pdf> Acesso em: 29 dez. 2018.

GUMBRECHT, Hans Ulrich. Serenidade, presença e poesia. Seleção e Tradução de Mariana Lage. - Belo Horizonte, MG: Relicário Edições, 2016.

HABERMAS, Jürgen. Era das Transições. Tradução de Flávio Beno Siebneichler Rio de Janeiro: Tempo Brasileiro, 2003.

KELSEN, Hans. Teoria Pura do Direito. São Paulo: Martins Fontes, 2013. 